\title{
Physicochemical properties of mulberry extract and silk protein added yogurt fermented with lactic acid bacteria isolated from vinegar and kimchi
}

\author{
Seong-Yeop Jeong' ${ }^{1}$ Suna Kang ${ }^{2}$ Min Joo Kim² - Eun Seon Kang \\ Xuangao $\mathrm{Wu}^{2} \cdot \mathrm{Na}$ Ra Lee ${ }^{3} \cdot$ Sunmin Park ${ }^{2}$
}

\section{김치와 식초 유래 젓산균으로 발효시킨 오디와 실크 단백질을 첨가한 발효유의 물리 화학적 특성 연구}

\author{
정성엽 ${ }^{1}$ - 강선아 ${ }^{2}$. 김민주 ${ }^{2} \cdot$ 강은선 $^{2} \cdot$ 오현호 $^{2} \cdot$ 이나라 $^{3} \cdot$ 박선민 $^{2}$
}

\begin{abstract}
The purpose of this study was to produce mulberry extract and silk protein (MS) added yogurt fermented with vegetable lactic acid bacteria (Lactobacillus plantarum and Bacillus acidiproducens) and to determine their physicochemical properties and preference. The physicochemical properties were examined total phenol and antocyanins contents, viscosity, visible cell counts, chromaticity and sensory evaluation. Yogurt made with LP (PL) and BA (BA) had similar $\mathrm{pH}$ and titrable acidity and mulberry and $\mathrm{MS}$ addition made lower $\mathrm{pH}$ and higher titrable acidity than the control (YF) $(p<0.05)$. The MS added yogurt exhibited adaptable acidity in the market. As expected, MS added yogurt had higher redness, and lower lightness and yellowness
\end{abstract}

Seong-Yeop Jeong and Suna Kang contributed equally to this work.

Sunmin Park $(\bowtie)$

E-mail: smpark@hoseo.edu

${ }^{1}$ Microbial Institute for Fermentation Industry, Soonchang-gun, 56048, Republic of Korea

${ }^{2}$ Dept. of Food \& Nutrition, Institute of Basic Science, Hoseo University, Asan-si, 31499, Republic of Korea

${ }^{3}$ Dept. of Nanobiotronics, Hoseo University, Asan-si, 31499, Republic of Korea

This is an Open Access article distributed under the terms of the Creative Commons Attribution Non-Commercial License (http://creativecommons. org/licenses/by-nc/3.0/) which permits unrestricted non-commercial use, distribution, and reproduction in any medium, provided the original work is properly cited. than no added one regardless of bacteria kinds, in chromaticity $(p<0.05)$. MS added yogurt showed higher value of total phenols and anthocyanins than no MS added one. MS added yogurt also increased the number of live bacteria in the ascending order of than LP, BA, YF, LP + MS, and BA + MS. In sensory evaluation, $\mathrm{BA}+\mathrm{MS}$ had the higher overall acceptance than the others. In conclusion, yogurt fermented with Lactobacillus plantarum and Bacillus acidiproducens was acceptable as much as the commercial Lactobacillus. Moreover, MS added yogurt fermented with Bacillus acidiproducens was the most preferred, based on physicochemical properties and overall acceptability for sensory evaluation.

Keywords Bacillus acidiproducens $\cdot$ Lactobacillus plantarum . Mulberry $\cdot$ Silk protein $\cdot$ Viscosity $\cdot$ Yogurt

서 론

기록에 의하면 한국은 고구려 시대부터 발효식품을 만들어왔다 는 서적이 존재할 정도로 오랜 발효식품의 역사를 가지고 있다 (Lee 1988). 역사적으로 중국과 일본의 영향을 많이 받았으나 한국 고유의 대표 발효식품으로 알려진 것은 된장, 고추장, 식 혜, 김치가 있으며, 전통식품의 항암효과(Park 1997), 항비만 효 과(Kwon 등, 2010), 면역력 증진효과(Lee 등, 2011) 등 다양한 효과들이 보고되고 있다. 발효유는 전통발효식품에 비해 한국에 
서 오랜 역사를 지닌 식품은 아니지만 소화를 돕고 면역력을 높이는 기능성식품으로, 높은 선호도를 가지는 식품 중 하나다 (Ahn 등, 2006). 기존에 발효유는 건강과 장수에 도움을 주는 웰빙 식품으로 알려져 있었지만, 최근에는 발효유가 비만에 효 과적이라는 연구들이 제기(Kadooka 등, 2010; Delzenne 등, 2011)되면서 비만에 관심이 많은 젊은 연령층의 발효유 구매율 이 높아져 발효유 시장이 더욱 확대되고 있다.

발효유를 제조하는데 쓰이는 유산균(lactic acid bacteria)은 유 당이나 포도당을 이용하여 젖산을 형성하는 균으로(Kim 등, 2015) 젖산균이라고도 불린다. 섭취한 젖산균은 장까지 도달해 나쁜 균의 증식은 억제하고 좋은 균의 증식을 돕는 역할을 하 며(Cho 등, 2011) 혈압감소(Seppo 등, 2003), 면역력 증가, 장 기능 활성화, 콜레스테롤 완화 등의 효과(Kim 등, 2015)가 있 다. 또한 연구에 따르면 장내 미생물은 사람의 건강과 질병에 큰 영향을 미치며 $(\mathrm{Kim}$ 등, 2014) 장내 유익균을 증진시키는 발 효유를 섭취하면 건강을 유지하는데 도움을 준다고 보고하는 연 구(Bang 등, 2012; Jo 등, 2014)도 존재한다.

염소젖을 원료로 제조한 발효유(Farnsworth 등, 2006), 대두 나 콩을 사용하여 발효유(Shin 등, 2012)를 제조하는 등 다양한 원료를 이용한 발효유 연구가 존재하며, 백년초(Lee와 Bae, 2009), $\gamma$-aminobutyric acid (Yim 등, 2012) 등을 첨가한 기능 성 발효유를 개발하는 다양한 연구가 이루어지고 있다. 오디 (Morus alba, Mulberry)는 당도와 산도가 높아 첨가물로 사용하 기에 좋고(Choi 등, 2012), 항산화 능력이 뛰어난 식품(Kim 등, 2007)으로 알려져 있고, 실크 단백질은 아미노산이 풍부하고 인 슐린의 활성을 돕고(Jang 등, 2003) tumor necrosis factor- $\alpha$, free fatty acid 감소 효과(Yuan 등, 2014), 면역력 증진 효과 (Hyen 2004)를 가진 식품이다.

유산균이 장까지 도달해야 그 이로운 영향을 미칠 수 있으므 로, 위산에서 파괴되지 않고 견딜 수 있는 발효유를 제조하는 연구들이 진행되고 있다. 초기 발효유를 제조에 쓰인 유산균은 동물성 유산균으로 L. bulgaricus와 S. thermophilus가 대표적이 다. 그러나 이러한 동물성 유산균은 $\mathrm{pH} 1$ 에서는 거의 2시간이 상 생존하지 못하고 $\mathrm{pH}$ 2.5에서 소량 생존한다는 보고가 존재 할 정도로(Conway 등, 1987) 위산에서 살아남아 장까지 도달 하는 량이 적다. 반면 식물성 유산균은 산성 환경에서 성장하 는 것들이어서 내산성이 강하여 장까지 도달하는 량이 동물성 유산균에 비하여 많고, 특히 채식주의자들에게 호평을 받고 있 다(Molin 2001).

그러므로 본 실험에서는 젓산을 생성하여 발효유 제조가 가 능한 김치에서 분리한 Lactobacillus plantarum 균과 식초에서 분리한 Bacillus acidiproducens 균을 이용하여 발효유를 제조하 고, 기능성이 뛰어난 오디 추출물과 실크 단백질을 첨가한 발 효유를 제조하여 그 물리화학적 특성을 조사하고자 한다.

\section{실험 재료 및 방법}

\section{시약 및 원료}

본 연구에서 사용한 실크 단백질은 (주)웰드웨이(Yeongi-gun, $\mathrm{Korea})$ 에서 공급 받아 $4{ }^{\circ} \mathrm{C}$ 에서 보관하여 실험에 사용하였다. 냉동 오디를 $4{ }^{\circ} \mathrm{C}$ 에서 녹여 착즙기로 짜서 용출액을 사용하였
다. 발효유의 생리활성 측정에 사용된 시약은 대부분 SigmaAldrich (St. Louis, MO, USA) 및 Merck (Darmstadt, Germany) 에서 구입하여 사용하였으며, 그 외의 시약은 특급이상의 시약 을 사용하였다. 실험에 사용된 유산균은 전통발효식품인 발효식 초로부터 자체 분리 동정한 Bacillus acidiproducens VG1 (BA)와 (재)발효미생물산업진흥원(MIFI, Sunchang-gun, Korea) 으로부터 분양 받은 Lactobacillus plantarum YD09 (LP)을 이용 하였으며, 대조군으로는 상업용으로 판매되고 있는 복합균주 ABT-4 (Lactobacillus acidophilus, Streptococcus thermophilus, and Bifidobacterium; Probio-Tec ${ }^{\circledR}$ blended culture, Hansen, Denmark)를 사용하였다. 실험에 사용한 유산균은 MRS 액체배 지(Difco, Detroit, MI, USA)에서 3회 계대 배양하여 활성화 시킨 후 실험에 사용하였다.

\section{균주 분리 및 커드형성 균주 선별}

각각의 유산균(YF, $\mathrm{LP}, \mathrm{BA})$ 을 $0.004 \%$ bromocresol purple 첨 가한 $\mathrm{MRS}$ 평판배지에 도말하여 배양하고 $\left(30^{\circ} \mathrm{C}, 24\right.$ 시간) 노란색 의 환을 형성하는 균주를 선별하여 $\mathrm{MRS}$ 액체 배지에 배양 $\left(30{ }^{\circ} \mathrm{C}, 24\right.$ 시간)하였다. 실험에 사용하기 전, 각각 유산균과 $20 \%(\mathrm{v} / \mathrm{v})$ glycerol을 $1: 1$ 의 비율로 혼합하여 $-80{ }^{\circ} \mathrm{C}$ 에서 보관하 였고, 실험에 사용하기 전, 유산균을 액체배지에 2회 계대 배양 하여 활성을 높인 뒤 발효유 제조에 사용하였다.

커드(curd)형성 유산균을 선발하기 위해 $10 \%$ skim milk broth (Difco)에 배양한 유산균 균주를 각각 $2 \times 10^{8} \mathrm{CFU} / \mathrm{mL}$ 를 $0.02 \%$ 접종하여 $37^{\circ} \mathrm{C}$ 에서 4 일간 배양하여 커드 형성능력이 좋 은 균주를 1 차로 선발하였고, 1 차 선발한 균주를 대상으로 $10 \%$ skim milk broth에 1차에 선발된 유산균을 각각 $2 \times 10^{8} \mathrm{CFU} /$ $\mathrm{mL}$ 를 $0.02 \%$ 로 접종하여 $37^{\circ} \mathrm{C}$ 에서 4 일간 배양하여 향이 좋고 산과 커드 형성 능력이 좋은 균주를 최종적으로 선발하였다.

\section{발효유 제조}

제조한 발효유의 배합비는 Table 1과 같다. 대조군의 3차 증류 수에 탈지분유(Seoul-milk, Seoul, Korea) $10 \%$, 설탕(CJ, Seoul, Korea) $2.0 \%$ 를 넣어 발효유 base를 제조하고 오디-실크 단백질 첨가군은 오디와 실크 단백질을 $2: 1$ 로 혼합한 시료를 $2.0 \%$ 넣 어 발효유 base를 제조하였다. 이때 오디-실크 단백질 첨가군은 설탕과 탈지분우유의 양에서 오디의 설탕 함량, 실크 단백질의 단백질 함량을 감안하여 모든 군에서 전체 양을 동일하게 만들 었다. 군별로 제조한 base는 고압멸균기(AC-12 autoclave, Jeio tech, Deajeon, Korea)에서 $121{ }^{\circ} \mathrm{C}$ 에서 $15 \mathrm{~min}$ 동안 멸균하였다. 클린벤치(CLB-201-04 vertical laminar flow cabinet, $\mathrm{CHC}$ lab, Deajeon, Korea)에서 $37-40{ }^{\circ} \mathrm{C}$ 까지 식힌 후, 선별된 균주를 접종하였고, base에 $2.0 \times 10^{4} \mathrm{CFU} / \mathrm{mL}$ 의 유산균이 되도록 접종 하였다. 이 혼합물을 24 시간 동안 $37^{\circ} \mathrm{C}$ incubator (IB-600M incubator, Jeio tech, Deajeon, Korea)에서 발효시켜 제조하였다. 제조가 완료된 발효유는 4에서 냉장보관 하였다.

\section{총 페놀 및 안토시아닌 함량 측정}

총 페놀 함량은 Folin-Ciocalteu의 방법으로 Velioglu(1998)의 실험방법을 응용하여 측정하였다. 완성된 발효유 $10 \mathrm{mg} / \mathrm{mL}$ 을 덜고 $70.0 \%$ methanol과 혼합한 혼합액을 제조한 후, 혼합액에 서 $0.1 \mathrm{~mL}$ 를 채취한 용액에 $2 \% \mathrm{Na}_{2} \mathrm{CO}_{3} 2 \mathrm{~mL}$, folin-ciocalteu 
Table 1 Yogurt composition made of different kinds of bacteria and mulberry extract+silk protein supplementation

\begin{tabular}{|c|c|c|c|c|c|}
\hline Group & Bacteria & Water $(\mathrm{mL})$ & Skim milk (g) & Sugar $(g)$ & Mulberry+silk protein $(2: 1)(\mathrm{g})$ \\
\hline YF & Probio-Tec ${ }^{\mathbb{B}}$ blended culture (ABT-4) & 500 & 50 & 10 & \\
\hline LP & Lactobacillus plantarum YD09 & 500 & 50 & 10 & \\
\hline BA & Bacillus acidiproducens VG1 & 500 & 50 & 10 & \\
\hline $\mathrm{LP}+\mathrm{MS}$ & Lactobacillus plantarum YD09 & 491 & 45 & 9 & 15 \\
\hline $\mathrm{BA}+\mathrm{MS}$ & Bacillus acidiproducens VG1 & 491 & 45 & 9 & 15 \\
\hline
\end{tabular}

reagent (Sigma) $0.2 \mathrm{~mL}$ 를 혼합하여 실온에서 30분간 암반응 시 키고, 비색 정량기(Perkin Elmer, Waltham, MA, USA)로 725 $\mathrm{nm}$ 에서 측정하였다. 정량을 위해 검량선은 caffeic acid (Sigma, Missouri, MO, USA)를 $70.0 \%$ 메탄올에 $10 \mathrm{mg}$ caffeic acid/ $\mathrm{mL}$ 로 용해시켜 $20,30,40,50 \mu \mathrm{g}$ caffeic acid $/ \mathrm{mL}$ 가 되도록 조제한 후 시료 용액과 같은 방법으로 처리하여 $725 \mathrm{~nm}$ 에서 흡 광도를 측정하여 작성하였다. 샘플의 총페놀 함량의 단위는 caffeic $\mathrm{acid} / \mathrm{mL}$ 로 표시하였다.

총안토시아닌 함량은 다른 $\mathrm{pH}$ 에서의 비색 정량으로 측정하 는 Giusti와 Wrolstad(2001)의 방법을 사용하였다(Nho 등, 2013). $\mathrm{A}$ 용액 $(0.2 \mathrm{M} \mathrm{KCl}, \mathrm{pH} 1.0)$ 과 $\mathrm{B}$ 용액 $(0.2 \mathrm{M}$ potassium phosphate, $\mathrm{pH} 4.5)$ 용액을 발효유에 1:20으로 혼합한 후 비색 정량기를 이 용하여 $520,700 \mathrm{~nm}$ 에서 측정하여 안토시아닌 함량을 $\mathrm{mg}$ cyanidin-3-glucoside equivalent $/ \mathrm{mL}$ 로 나타내었다. 함량 계산은 Nho 등(2013)의 계산식을 참고하여 계산하였다.

\section{$\mathrm{pH}$ 및 산도 측정}

발효 초기의 0 시간을 포함하여 발효가 진행되는 중 $6,12,24$ 시간 발효유의 $\mathrm{pH}$ 를 $\mathrm{pH}$ meter (Orion 3-star Benchtop $\mathrm{pH}$ meter, Thermo Fisher Scientific Inc, Waltham, MA, USA)를 사용하여 측정하였다. 결과 값은 3 회 반복 측정하여 평균값으 로 나타내었다. 유기산 측정 시간은 $\mathrm{pH}$ 를 측정과 동시에 하였 는데, 3 차 증류수로 발효유를 $1: 1$ 로 희석하고 filtering하여 걸 러진 유청에 $0.1 \mathrm{~N} \mathrm{NaOH}$ 로 $\mathrm{pH}$ 8.4가 될 때까지 넣어 적정 산도를 측정하였다.

\section{생균수 측정}

발효유의 유산균 수 측정은 $\mathrm{MRS}$ 고체배지를 이용하여 표준평 판배양법으로 균수를 측정 하였다. 접종직후( 0 시간), $6,12,24$ 시간, 48 시간 후 10 배 희석법으로 희석하여, $37^{\circ} \mathrm{C} 48$ 시간 배 양 후 균수를 colony forming unit $(\mathrm{CFU}) / \mathrm{mL}$ 로 나타내었고 3 회 측정하여 측정치를 비교하였다.

\section{색도 측정}

발효유의 색도측정은 제조한 발효유를 $4{ }^{\circ} \mathrm{C}$ 에서 24 시간 보관 후 색차계(JC-801S, Color Techno System, Konica Minolta, Tokyo, Japan)로 측정하였다. 명도를 나타내는 L값(lightness), 적 색도를 나타내는 $\mathrm{a}$ 값(redness), 황색도를 나타내는 $\mathrm{b}$ 값 (yellowness)으로 나타내었고, 9회 반복하여 평균값으로 나타내 어 측정값을 비교하였다.

\section{점도 측정}

발효유의 점도는 점도계(LVDV-II + Pro Brookfiled Engineering
Lab. Inc., Middleborough, MA, USA)를 사용하였고, spindle은 6 번을 사용하여 점도를 측정하였고, 점도 단위는 centi-poise (CP)로 사용하였다(Lee와 Lucey 2010). 발효 완료 후 24시간 $4{ }^{\circ} \mathrm{C}$ 에서 24 시간 냉장보관 후 실온에서 $30 \mathrm{rpm}$ 에서 30 초 간격 으로 2 분 동안 측정하였다.

\section{관능검사}

각 발효유에 대한 기호도 조사를 위해 평소 발효유 제품을 자 주 섭취하는 대학생 40 명을 대상으로 실시하였으며, blind test 로 관능검사를 진행하였다. 검사 전 후 물로 입을 헹구고 실행 하는 검사 방법을 숙지시킨 후 색, 향, 단맛, 신맛, 전체적기호 도에 대하여 각 항목별 가장 나쁜 것 1점, 가장 좋은 것 5 점의 5 단계 평가를 하도록 하였다.

\section{통계분석}

본 실험의 모든 통계처리는 SPSS (Statistical Package for Social Science, version 18.0)를 이용하여 평균 \pm 표준오차로 나 타내었고, 사용한 균주에 따른 차이와 오디 + 실크 단백질 첨가 에 따른 차이는 two-way ANOVA로 통계적 유의성을 측정하였 다. ANOVA로 측정한 실험군 내에서 통계적 유의성의 차이는 Tukey test로 $p<0.05$ 의 수준에서 검정하였다.

\section{결과 및 고찰}

\section{총 페놀 및 안토시아닌 함량}

발효유를 제조하여 24시간 안정화 시킨 후 발효유의 총 페놀과 안토시아닌 함량을 측정하였다(Table 2). 총 페놀 함량은 $\mathrm{MS}$ 를 넣지 않은 군들에서 상당량 함유되어 있었지만 $\mathrm{MS}$ 를 첨가하였 을 때 급증하는 것을 볼 수 있었다. Bacteria의 종류는 총페놀 함량에 영향을 미치지 않아서 총페놀 함량은 $\mathrm{BA}+\mathrm{MS}, \mathrm{LP}+\mathrm{MS}$ 군들이 $\mathrm{YF}, \mathrm{LP}, \mathrm{BA}$ 군들보다 통계적으로 유의하게 높았다. 총 안토시아닌 함량도 페놀의 결과와 유사한 양상을 띄었는데, YF, $\mathrm{BA}, \mathrm{LP}$ 군들에서는 총 안토시아닌 함량이 매우 낮았으며 $\mathrm{MS}$ 를 첨가했을 때 급격하게 증가하였으며 이 함량도 bacteria의 종류 에 의해서는 영향을 받지 않았다. 오디+실크 단백질의 첨가가 총 안토시아닌과 총 페놀 함량을 증가시킨 것은 오디에 안토시 아닌이 많이 함유되어 있는 것과 관련이 있다(Liu 등, 2004). 안토시아닌은 열에 불안정하여 $70{ }^{\circ} \mathrm{C}$ 이상에서 짧은 시간 가공 하는 동안에도 파괴가 많이 일어나는데(Patras 등, 2010), $37^{\circ} \mathrm{C}$ 에서 24시간 동안 공기에 접촉하면서 발효하는데도 안토시아닌 의 파괴가 아주 높지는 않은 것으로 보아 공기보다는 열이 안 토시아닌 파괴에 중요한 역할을 하는 것을 사료된다. 
Table 2 Total phenol contents result of yogurt fermented by different bacteria and adding mulberry extract + silk protein (MS)

\begin{tabular}{ccc}
\hline \hline & $\begin{array}{c}\text { Total phenolic compounds } \\
(\mathrm{mg} \text { caffeic acid equivalent/ } \\
\mathrm{mL})\end{array}$ & $\begin{array}{c}\text { Total anthocyanin } \\
\text { compounds (mg cyanidin- } \\
\text { 3-glucoside equivalent } / \mathrm{mL})\end{array}$ \\
\hline YF & $13.9 \pm 0.01^{\mathrm{b}}$ & $0.49 \pm 0.21^{\mathrm{b}}$ \\
LP & $13.9 \pm 0.05^{\mathrm{b}}$ & $0.24 \pm 0.12^{\mathrm{b}}$ \\
BA & $13.9 \pm 0.03^{\mathrm{b}}$ & $0.37 \pm 0.22^{\mathrm{b}}$ \\
LP + MS & $21.1 \pm 0.03^{\mathrm{a}}$ & $3.11 \pm 0.34^{\mathrm{a}}$ \\
BA + MS & $21.6 \pm 0.08^{\mathrm{a}}$ & $3.41 \pm 0.28^{\mathrm{a}}$ \\
\hline
\end{tabular}

YF, LP and BA were inoculated with Probio-Tec ${ }^{\circledR}$ blended culture (ABT4), L. plantarum and B. acidiproducens, respectively Values are mean $\pm \mathrm{SE}(\mathrm{n}=6)$

${ }^{\mathrm{a} \sim \mathrm{c}}$ Different alphabets in the same row indicate significant differences among the groups by Tukey's test at $p<0.05$

\section{$\mathrm{pH}$ 와 산도}

유산균의 종류와 시간에 따른 $\mathrm{pH}$ 와 유기산의 차이는 Table 3 에 나타내었다. 각 군마다 초기에 발효 시작 시 $\mathrm{pH}$ 값은 $6.65 \pm$ 0.05 로 유사한 값을 나타내었고 발효 완료 시점에는 $\mathrm{YF}$ 와 오 디 + 실크 단백질 첨가군이 유의적으로 낮은 값을 나타내었으며 $\mathrm{BA}+\mathrm{MS}$ 가 가장 낮은 값을 나타내었다. 발효가 진행되는 동안 $\mathrm{LP}$ 와 $\mathrm{BA}$ 군은 오디 + 실크 단백질 첨가 군에 비하여 값이 낮아 지는 폭이 적었다. 발효 초기 유기산 값은 $\mathrm{BA}$ 가 가장 낮은 값 을 나타내었지만 $0.14 \pm 0.02$ 로 유사한 값을 나타내었다. 발효 완료 시점에 오디+실크 단백질을 첨가한 것이 유의적으로 높은 유기산 값을 나타내었고, $\mathrm{YF}, \mathrm{LP}, \mathrm{BA}$ 순으로 높은 유기산 값을 나타내었다. 발효가 진행되는 시간에서도 발효 완료 시점의 결 과와 유사한 양상을 보였는데, 오디+실크 단백질 첨가군의 유 기산 값이 더 높게 나타났다.

$\mathrm{pH}$ 결과와 유기산량은 유사한 결과를 나타내었는데, $\mathrm{pH}$ 값 이 낮을수록 유기산량은 높은 값을 나타내는 경향을 보였다. 오 디 + 실크 단백질 첨가 군이 다른 군보다 $\mathrm{pH}$ 는 낮고, 유기산량 은 높았다. 이는 유산균의 유기산에 더해 오디의 유기산이 더 해져 $\mathrm{pH}$ 값이 더 낮게, 유기산량은 더 높게 나온 것으로 보인다. Yang 등(2016)의 오디 농축액 첨가에 따른 식혜의 $\mathrm{pH}$ 결과, 오
디의 첨가량이 많아지면 초기 $\mathrm{pH}$ 값이 낮아졌다. Celik와 Bakirci(2003)도 오디 청을 첨가한 발효유의 $\mathrm{pH}$ 에서 오디 첨가 량이 증가할수록 초기부터 낮은 $\mathrm{pH}$ 값을 나타내는 경향을 보였 다. 하지만 발효 후반기에는 대조군보다 높은 $\mathrm{pH}$ 를 나타내었다 고 보고하였는데, 이는 오디첨가군 발효유의 산도가 높아지면서 $\mathrm{pH}$ 는 낮아져 박테리아의 젖산 형성을 방해하여, 대조군보다 $\mathrm{pH}$ 는 높고 산도는 낮은 값을 나타냈다고 보고하였다. 이들은 $S$. thermophilus, L. bulgaricus, B. longum 균주를 사용하였고 낮 은 $\mathrm{pH}$ 와 높은 산도에서 젖산의 형성이 지연되어 발효 후반기 에 변화가 나타난 것으로 사료된다. 그러나 본 실험에서는 내 산성이 강한 식물성 유산균을 사용하여 오디 + 실크 단백질을 첨가에도 $\mathrm{pH}$ 와 산도에서 지속적으로 좋은 값을 나타낸 것으로 사료된다.

\section{생균수 측정}

발효유의 발효 초기, $6,12,24$ 시간 발효시기의 생균수 결과는

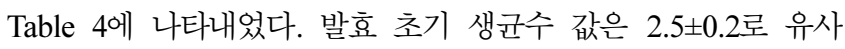
한 값을 나타내었고, 발효가 진행될수록 군 간의 차이는 급격 하게 변화했다. 12 시간 발효시점부터 오디 + 실크 단백질 첨가 군과 첨가하지 않은 군 간에 차이가 있었는데, 대조군인 $\mathrm{YF}$ 를 제외하고 오디와 실크 단백질 첨가군의 생균수 값이 유의적으 로 높은 값을 나타내었다 $(p<0.05)$. 발효 완료 시점의 생균수 결 과 값은 $\mathrm{YF}: 7.0 \times 10^{8}, \mathrm{LP}: 4.9 \times 10^{8}, \mathrm{BA}: 5.3 \times 10^{8}, \mathrm{LP}+\mathrm{MS}$ : $9.2 \times 10^{8}, \mathrm{BA}+\mathrm{MS}$ : $9.4 \times 10^{8} \mathrm{CFU} / \mathrm{mL}$ 로 농후 발효유로써 적합 한 결과를 나타내었다. $\mathrm{BA}$ 와 $\mathrm{LP}$ 군은 시판되는 발효유의 생균 수보다 낮은 값을 나타내었지만(Shin 등, 2009) 오디 + 실크 단 백질을 첨가하였을 때 생균수 값이 높아진 것으로 보아 오디 + 실크 단백질이 발효유 내 생균수가 증식하는데 도움을 준 것으 로 사료된다. Shin 등(2015)은 자색당근을 첨가한 발효유의 품 질에 대해 연구하였는데, 발효한 자색당근의 추출물을 첨가한 발효유의 생균수에서 유의적으로 높은 값을 나타냈다고 보고하 였다. 또한, 동물성 유산균으로 발효시킨 발효유에서는 오디 첨 가하였을 때 생균수 값이 높다고 보고한 바 있다(Sung과 Choi, 2014). Suh 등(2006)은 $1,5,10 \%$ 의 오디를 첨가하여 발효유를 제조하였는데, $1 \%$ 첨가군에서 가장 높은 생균수 값을 나타내었

Table $3 \mathrm{pH}$ and titrable acid of yogurt made of different bacteria and mulberry extract+silk protein(MS) supplementation

\begin{tabular}{|c|c|c|c|c|c|}
\hline & & \multicolumn{4}{|c|}{ Fermentation periods (hours) } \\
\hline & & 0 & 6 & 12 & 24 \\
\hline \multirow{5}{*}{$\mathrm{pH}$} & YF & $6.67 \pm 0.01^{\mathrm{b}}$ & $6.22 \pm 0.01^{\mathrm{b}}$ & $4.71 \pm 0.02^{b}$ & $4.31 \pm 0.01^{\mathrm{b}}$ \\
\hline & LP & $6.69 \pm 0.01^{\mathrm{b}}$ & $6.12 \pm 0.03^{\mathrm{ab}}$ & $5.17 \pm 0.03^{\mathrm{c}}$ & $4.63 \pm 0.01^{\mathrm{c}}$ \\
\hline & BA & $6.67 \pm 0.01^{\mathrm{b}}$ & $6.14 \pm 0.02^{\mathrm{ab}}$ & $5.11 \pm 0.04^{\mathrm{c}}$ & $4.74 \pm 0.01^{\mathrm{d}}$ \\
\hline & $\mathrm{LP}+\mathrm{MS}$ & $6.60 \pm 0.01^{\mathrm{a}}$ & $5.89 \pm 0.08^{\mathrm{a}}$ & $4.49 \pm 0.03^{\mathrm{a}}$ & $4.31 \pm 0.01^{\mathrm{b}}$ \\
\hline & $\mathrm{BA}+\mathrm{MS}$ & $6.60 \pm 0.01^{\mathrm{a}}$ & $6.16 \pm 0.06^{b}$ & $4.46 \pm 0.01^{\mathrm{a}}$ & $4.20 \pm 0.01^{\mathrm{a}}$ \\
\hline \multirow{5}{*}{$\begin{array}{c}\text { Titrable acidity } \\
(\%)\end{array}$} & YF & $0.14 \pm 0.01^{\mathrm{ab}}$ & $0.25 \pm 0.02^{\mathrm{ab}}$ & $0.46 \pm 0.03$ & $0.85 \pm 0.03^{\mathrm{b}}$ \\
\hline & LP & $0.14 \pm 0.01^{\mathrm{ab}}$ & $0.25 \pm 0.02^{\mathrm{ab}}$ & $0.54 \pm 0.05$ & $0.83 \pm 0.03^{\mathrm{b}}$ \\
\hline & $\mathrm{BA}$ & $0.12 \pm 0.01^{\mathrm{b}}$ & $0.22 \pm 0.02^{\mathrm{b}}$ & $0.52 \pm 0.07$ & $0.75 \pm 0.01^{\mathrm{b}}$ \\
\hline & $\mathrm{LP}+\mathrm{MS}$ & $0.16 \pm 0.01^{\mathrm{a}}$ & $0.34 \pm 0.03^{\mathrm{a}}$ & $0.69 \pm 0.04$ & $0.96 \pm 0.01^{\mathrm{a}}$ \\
\hline & $\mathrm{BA}+\mathrm{MS}$ & $0.16 \pm 0.01^{\mathrm{a}}$ & $0.28 \pm 0.01^{\mathrm{ab}}$ & $0.67 \pm 0.09$ & $0.98 \pm 0.01^{\mathrm{a}}$ \\
\hline
\end{tabular}

YF, LP and BA were inoculated with Probio-Tec ${ }^{\mathbb{}}$ blended culture (ABT-4), L. plantarum and B. acidiproducens, respectively

Values are mean $\pm \mathrm{SE}(\mathrm{n}=3)$

${ }^{\mathrm{a} \sim \mathrm{d}}$ Different alphabets in the same row indicate significant differences among the groups by Tukey's test at $p<0.05$ 
Table 4 The number of visible cells of yogurt made of different bacteria and mulberry extract + silk protein (MS) supplementation during fermentation

(unit: $\mathrm{CFU} / \mathrm{mL}$ )

\begin{tabular}{|c|c|c|c|c|}
\hline & \multicolumn{4}{|c|}{ Fermentation periods (h) } \\
\hline & $0\left(10^{4}\right)$ & $6\left(10^{6}\right)$ & $12\left(10^{8}\right)$ & $24\left(10^{8}\right)$ \\
\hline $\mathrm{YF}$ & $2.67 \pm 0.39$ & $3.34 \pm 0.63$ & $2.60 \pm 0.28^{\mathrm{ab}}$ & $6.97 \pm 0.36^{\mathrm{b}}$ \\
\hline LP & $2.37 \pm 0.22$ & $2.14 \pm 0.22$ & $1.31 \pm 0.33^{\mathrm{b}}$ & $4.93 \pm 0.08^{\mathrm{c}}$ \\
\hline $\mathrm{BA}$ & $2.37 \pm 0.12$ & $1.31 \pm 0.44$ & $1.74 \pm 0.44^{\mathrm{b}}$ & $5.37 \pm 0.18^{\mathrm{c}}$ \\
\hline $\mathrm{LP}+\mathrm{MS}$ & $2.60 \pm 0.29$ & $2.21 \pm 0.49$ & $3.60 \pm 0.35^{\mathrm{a}}$ & $9.20 \pm 0.43^{a}$ \\
\hline $\mathrm{BA}+\mathrm{MS}$ & $2.70 \pm 0.10$ & $2.18 \pm 0.60$ & $3.60 \pm 0.35^{\mathrm{a}}$ & $9.40 \pm 0.40^{\mathrm{a}}$ \\
\hline
\end{tabular}

YF, LP and BA were inoculated with Probio-Tec ${ }^{\circledR}$ blended culture (ABT-4), L. plantarum and B. acidiproducens, respectively

Values are mean $\pm \mathrm{SE}(\mathrm{n}=3)$

${ }^{\mathrm{a} \sim \mathrm{c}}$ Different alphabets in the same row indicate significant differences among the groups by Tukey's test at $p<0.05$

Table 5 Chromaticity of yogurt fermented by different bacteria and adding mulberry extract + silk protein (MS)

\begin{tabular}{cccc}
\hline \hline & \multicolumn{3}{c}{ Chromaticity } \\
\cline { 2 - 4 } & $\mathrm{L}^{*}$ & $\mathrm{a}^{*}$ & $\mathrm{~b}^{*}$ \\
\hline YF & $80.6 \pm 0.43^{\mathrm{a}}$ & $3.52 \pm 0.41^{\mathrm{b}}$ & $17.0 \pm 0.44^{\mathrm{a}}$ \\
LP & $81.1 \pm 0.32^{\mathrm{a}}$ & $2.98 \pm 0.41^{\mathrm{b}}$ & $16.7 \pm 0.49^{\mathrm{a}}$ \\
BA & $80.6 \pm 0.38^{\mathrm{a}}$ & $3.30 \pm 0.41^{\mathrm{b}}$ & $16.8 \pm 0.47^{\mathrm{a}}$ \\
LP + MS & $62.0 \pm 0.52^{\mathrm{b}}$ & $9.84 \pm 0.12^{\mathrm{a}}$ & $10.0 \pm 0.20^{\mathrm{b}}$ \\
BA + MS & $60.0 \pm 0.11^{\mathrm{c}}$ & $9.86 \pm 0.07^{\mathrm{a}}$ & $9.10 \pm 0.13^{\mathrm{b}}$ \\
\hline
\end{tabular}

YF, LP and BA were inoculated with Probio-Tec ${ }^{\circledR}$ blended culture (ABT4), L. plantarum and B. acidiproducens, respectively. $\mathrm{L}^{*}$ : 0 yields black and 100 diffues white; $a^{*}$ : negative and positive values indicate green and magenta, respectively; $b^{*}$ : negative and positive values indicate blue and yellow, respectively

Values are mean $\pm \operatorname{SE}(n=9)$

${ }^{\mathrm{a} c}$ Different alphabets in the same row indicate significant differences among the groups by Tukey's test at $p<0.05$

고, 오디의 양이 $5,10 \%$ 로 증가하면서 생균수는 감소하였다. 이 것은 낮은 농도에서는 오디 추출물이 유산균의 증식을 촉진시 키지만, 오히려 농도가 너무 높아지면 저농도의 오디를 첨가한 것 보다 유산균의 성장을 억제하는 것으로 보인다. 본 실험에 서는 첨가된 오디+실크단백질의 농도는 $2 \%$ 로(오디 함량으로는 $1.3 \%) \mathrm{Suh}$ 등(2006)이 보고한 것과 유사한 경향을 나타내었고 약 $1 \%$ 의 오디의 첨가는 젖산균의 성장을 촉진시켜 오디+실크 단백질 발효유에서 높은 생균수 값을 나타낸 것으로 사료된다.

\section{색도 측정}

24 시간 동안 발효시킨 후 $4{ }^{\circ} \mathrm{C}$ 에서 24 시간 보관한 발효유로 색 도를 측정하였다. 오디 + 실크 단백질이 첨가된 발효유와 첨가 되지 않은 발효유간에 유의적인 차이가 존재했다(Table 5). 오 디 + 실크 단백질이 첨가된 발효유에서 명도와 황색도는 낮은 값을, 적색도는 높은 값을 나타내었다. 이것은 오디가 적색도를 높이는 것을 알 수 있었다. Kim 등(2009)은 버찌 분말을 첨가 한 발효유의 품질특성에서 버찌를 넣은 발효유의 명도와 황색 도는 낮고, 적색도에서 높은 값을 나타내었다고 보고하였다. 그 러므로 안토시아닌이 함유된 추출액을 첨가할 때 적색도가 높 아지고 황색도는 낮아지는 것을 알 수 있었다. 그러나 추출액 에 함유된 안토시아닌이 파괴되면 오히려 추출액을 함유한 제 품의 황색도가 높아지는 것을 볼 수 있었다(Nho 등, 2013). 그

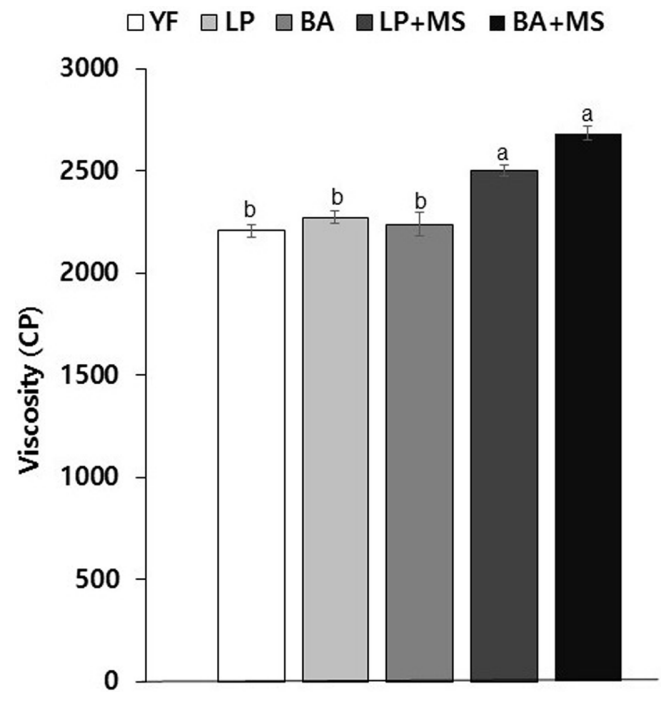

Fig. 1 Viscosity of yogurt fermented by different kinds of bacteria and adding mulberry extract+silk protein (MS) supplementation. YF, LP and BA were inoculated with Probio-Tec ${ }^{\circledR}$ blended culture (ABT-4), $L$. plantarum and B. acidiproducens, respectively. Values are mean $\pm \mathrm{SE}$ $(\mathrm{n}=6) .{ }^{\mathrm{a}, \mathrm{b}}$ Different alphabets in the same row indicate significant differences among the groups by Tukey's test at $p<0.05$

러므로 본 연구에서 발효과정에서는 안토시아닌의 파괴가 많이 일어나지는 않았다는 것을 알 수 있었다. 또한, $\operatorname{Kim}(2004)$ 은 실 크 단백질 첨가 빵의 품질 특성 및 기능성에 대하여 연구하였 는데, 빵에 함유된 실크 단백질 첨가량이 증가할수록 빵의 표 면이 어두워지는 것을 확인하였다. 이것은 굽는 과정에서 실크 단백질과 설탕이 Mailard 반응에 의한 것으로 사료된다. 본 연 구에서는 $37^{\circ} \mathrm{C}$ 에서 발효를 시켜서 실크단백질이 Mailard 반응 이 적게 일어났고 오디도 파괴되지 않아서 황색도가 증가하지 않은 것으로 보인다.

\section{점도 측정}

발효유의 점도 결과는 Fig. 1에 나타내었다. $\mathrm{BA}+\mathrm{MS}$ 가 가장 높은 점도 값을 나타내었고, $\mathrm{LP}+\mathrm{MS}, \mathrm{LP}, \mathrm{BA}, \mathrm{YF}$ 순으로 높 은 점도 값을 나타내었으며, 발효유에 오디 + 실크 단백질을 첨 가군이 유의적으로 높은 점도 값을 나타내는 경향을 보였는데 이는 첨가된 오디와 실크 단백질이 발효유가 커드를 형성하는 


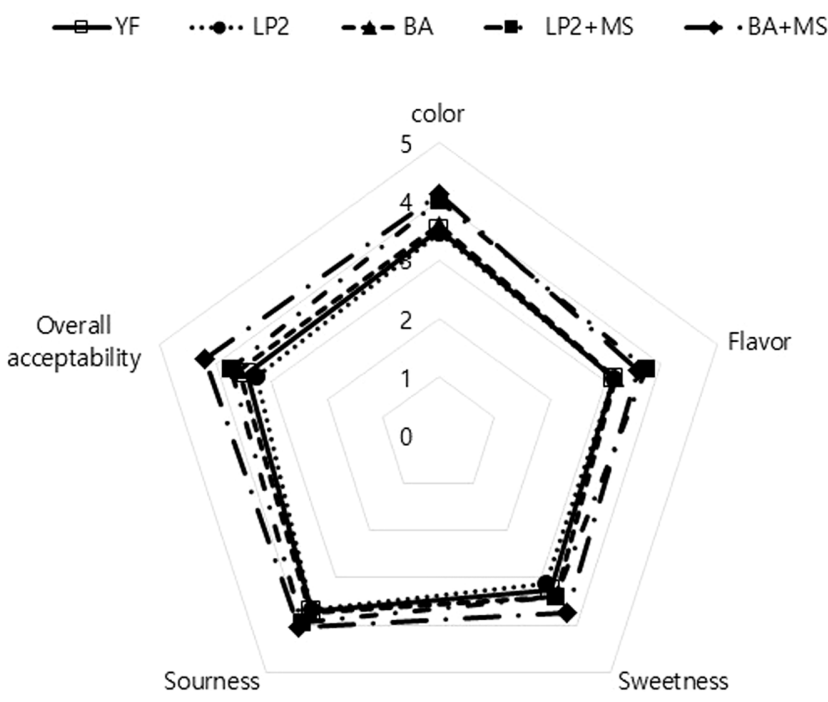

Fig. 2 Sensory evaluation of yogurt fermented by different kinds of bacteria and adding mulberry extract+silk protein (MS) supplementation. YF, LP and BA were inoculated with Probio-Tec ${ }^{\circledR}$ blended culture (ABT4), L. plantarum and B. acidiproducens, respectively. Values are mean \pm SE $(n=40)$

데 영향을 미친 것으로 보인다. 유자를 첨가하여 발효유를 제 조한 Lee 등(2008)은 유자 추출물 첨가 발효유가 무첨가군 보 다 높은 점도를 보였다고 보고하였으며, 알로에를 첨가한 발효 유의 물리화학적 특성은 연구한 Shin 등(1995)은 알로에 첨가 량이 증가할수록 산도와 점도 결과가 높게 나타났다고 보고한 바 있다. 발효유에 펙틴이나 젤라틴, 우유 등이 첨가되면 점도 결과가 달라질 수 있으므로(Sawatari 등, 2005), 오디+실크 단 백질이 첨가되어 발효유의 점도 값이 높게 나온 것으로 보인다.

\section{관능검사}

발효유를 제조한 후 $4{ }^{\circ} \mathrm{C}$ 에서 24 시간 안정화시킨 발효유로 관 능검사를 수행하였다(Fig. 2). 색과 향, 신맛 평가에서 유사한 결과를 나타내었는데, 오디+실크 단백질 첨가군이 첨가하지 않 은 군에 비하여 좋은 점수를 받았다. 전체적기호도는 $\mathrm{BA}+\mathrm{MS}$ 가 가장 좋은 점수를 받았고, $\mathrm{LP}+\mathrm{MS}, \mathrm{BA}, \mathrm{YF}, \mathrm{LP}$ 순으로 높 은 점수를 받았다. 김치유래 유산균인 L. plantarum 은 젖산을 만들어내는 능력이 뛰어나(Sawatari 등, 2005) 신맛이 강한 젖 산균으로 알려져 있다. 식초에서 분리한 B. acidiproducens 균 이 김치 균인 LP보다 신맛이 강해 기호도에서 낮은 점수를 받 을 것으로 예상하였으나, 향을 제외한 모든 평가에서 가장 좋 은 점수를 받았다. Cho 등(2011)은 한국 전통 식물성 유산균을 대두에 혼합하여 유산균 음료를 제조하였는데 L. plantarum은 상쾌한 신맛, B. subtilis는 부드러운 특징이 있다고 보고하였고 , 접종 균의 비율에 따라 발효 제품의 풍미가 좌우되었다고 보 고하였다. 관능평가에서는 B. acidiproducens 균과 L. plantarum 이 생성하는 유기산의 차이가 단맛이나 전체적 기호도에 가장 크게 영향을 미친 것으로 보이며, 또한 오디의 안토시아닌과 실 크 단백질이 이 젖산균의 성장과 대사산물을 변화시켜 젖산을 비롯한 다양한 유기산들이 생성되고 이것이 신맛이나 향에 영 향을 미친 것으로 사료된다. 저 농도의 오디 첨가는 유산균의
증식을 촉진시키는데 도움을 주고, 실크 단백질은 변비 개선에 도움을 주는 장점을 가지고 있으므로(Yeo 등, 2006) $B$. acidiproducens 균으로 발효시키고 오디 실크 단백질을 첨가하 여 발효유를 제조하였을 때 상품성이 높은 발효유 제품을 제조 할 수 있을 것으로 사료된다.

\section{초 록}

본 실험에서는 오디와 실크 단백질을 첨가하고 식물성 젖산균 인 Lactobacillus plantarum와 Bacillus acidiproducens로 발효 시킨 기능성 발효유를 제조하고 이들의 발효유의 물리화학적 품 질을 조사하고자 한다. 제조한 발효유의 물리화학적 특성과 품 질은 발효유의 총 페놀 함량 및 안토시아닌 함량, 점도, 색도 값을 측정하고 기호도를 조사하여 결정하였다. $\mathrm{LP}$ 와 $\mathrm{BA}$ 로 제 조한 발효유는 대조균주인 $\mathrm{YF}$ 과 유사한 $\mathrm{pH}$ 와 산도를 나타내었 으나, 오디와 실크 단백질을 첨가한 발효유는 유의적으로 낮은 $\mathrm{pH}$ 값와 높은 산도를 나타내었다. 발효유의 색도는 오디와 실크 단백질을 첨가한 발효유에서 높은 적색도와 낮은 명도, 황색도 값을 나타내었고, 생균수와 점도에서도 오디와 실크 단백질을 첨가한 발효유에서 높은 값을 나타내었다 $(p<0.05)$. 생균수의 경 우 $\mathrm{BA}+\mathrm{MS}, \mathrm{LP}+\mathrm{MS}, \mathrm{YF}, \mathrm{BA}, \mathrm{LP}$ 순으로 높은 값을 나타내 었는데, $\mathrm{YF}$ 를 기준으로 오디와 실크 단백질을 첨가한 발효유와 첨가하지 않은 발효유간의 유의적인 차이를 보였다. 관능평가에 서도 오디와 실크 단백질을 첨가한 발효유에서 높은 선호도를 보였으며, 전체적인 기호도에서는 $\mathrm{BA}+\mathrm{MS}, \mathrm{LP}+\mathrm{MS}, \mathrm{BA}$, $\mathrm{YF}, \mathrm{LP}$ 순으로 높은 점수를 받았고 식초에서 얻은 균으로 제 조한 발효유가 높은 선호도를 보였다. 결론적으로 김치 및 식 초 유래 유산균으로 발효유는 기존에 상업적으로 사용하는 유 산균으로 제조한 것과 물리화학적 특징에 차이가 없었다. 더 나 아가 오디추출물과 실크 단백질을 첨가한 발효유는 오디추출물 과 실크 단백질이 첨가되지 않은 발효유보다 물리화학적 품질 도 향상되고, 기호도도 높여서 향후 제품화 가능성도 기대할 수 있겠다.

Keywords 김치 유래 유산균 - 발효유-식초 유래 젖산균 - 실 크 단백질 - 오디 · 점도

감사의 글 본 연구는 산업통상자원부와 한국산업기술진흥원의 지역특화산 업육성(R\&D) 기술개발사업의 지원을 받아 수행된 연구 결과입니다(R0006422).

\section{References}

Ahn YT, Lim KS, Huh CS (2006) Current state of functional yogurt in Korea. J Kor Dairy Technol Sci 24: 29-42

Bang MS, Lee SD, Oh SJ (2012) Probiotics and intestinal health. Korean J Dairy Sci Technol 2: 139-143

Celik S, Bakirci I (2003) Some properties of yoghurt produced by adding mulberry pekmez (concentrated juice). International J Dairy Technol 56: 26-29

Cho EK, Cho HY, Kim BC, Shin HH, Cho SC, Kook MC, Pyun YR (2011) Development of pre-treatment and mixed culture processes for plant originated lactic acid to produce a functional lactic acid beverage. Kor $\mathrm{J}$ Food Nutr 1: 117-123 
Choi IS, Moon YS, and Kwak EJ (2012) Composition of resveratrol and other bio-active compounds, and antioxidant activities in different mulberry cultivars. Kor J Hort Sci Technol 30: 301-307

Conway PL, Gorbach SL, Goldin BR (1987) Survival of lactic acid bacteria in the human stomach and adhesion to intestinal cells. J Dairy sci 70: 112

Delzenne NM, Neyrinck AM, Bäckhed F, Cani PD (2011) Targeting gut microbiota in obesity: effects of prebiotics and probiotics. Nature Rev Endocrin 7: 639-646

Farnsworth JP, Li J, Hendricks GM, Guo MR (2006) Effects of transglutaminase treatment on functional properties and probiotic culture survivability of goat milk yogurt. Small Ruminant Res 65: 113-121

Giusti MM, Wrolstad RE (2001) Unit F1.2: Anthocyanins. characterization and measurement with UV-visible spectroscopy. In: Wrolstad RE, editor. Current protocols in food analytical chemistry. New York, USA, pp 1-13

Hyen CK (2004) Physiological activity of silk fibroin-derived peptides. Kor Soc Food Sci Nutr 9: 29-47

Jang KS, Cheong KS, Choi CH, Oh YJ (2003) Effect of bambusae caulis in liquamen and silk worm powder on blood sugar in $\mathrm{db} / \mathrm{db}$ mice. Korean $\mathrm{J}$ Oriental Physiol Pathol 17: 756-764

Jo JH, Yang HS, Choi YJ, Lee SC, Choi BS, Park TY, Kim JK, Huh CK (2014) Quality characteristics of protein-enriched fermented milk made with whey and soybean flour. Kor J Dairy Sci Technol 32: 121-129

Kadooka Y, Sato M, Imaizumi K, Ogawa A, Ikuyama K, Akai Y, Tsuchida T (2010) Regulation of abdominal adiposity by probiotics (Lactobacillus gasseri SBT2055) in adults with obese tendencies in a randomized controlled trial. Eur J Clin Nutr 64: 636-644

Kim AJ, Yuh CS, Bang IS, Park HY and Lee GS (2007) An investigation the preparation and physicochemical properties of oddi jelly using mulberry fruit powder. Korean J Food Nutr 1: 27-33

Kim DW, Yang TY, Lim JW, Lee KH, Cho SJ, Lee GH (2015) Study of lactic acid bacteria in yogurt on the market. J Sci Edu 1: 17-22

Kim HJ, Kang KM, Kim SJ, Im EO (2014) Recent update in fecal microbiota transplantation. Kor J Microbiol 4: 265-274

Kim KH, Hwang HR, Jo JE, Lee SY, Kim NY, Yook HS (2009) Quality characteristics of yogurt prepared with flowering cherry (Prunu serrulata L. var. spontanea max. wils.) fruit powder during storage. J Korean Soc Food Sci Nutr 38: 1229-1236

Kim YH (2004) Quality and functionality of silk peptide bread. Korean Soc Food Sci Nutr 9: 48-61

Kwon DY, Daily JW, Kim HJ, Park SM (2010) Antidiabetic effects of fermented soybean products on type 2 diabetes. Nutr Res 30: 1-13

Lee CH, Youn Y, Song GS, Kim YS (2011) Immuno-stimulatory effects of traditional Doenjang. J Korean Soc Food Sci Nutr 40: 1227-1234

Lee JY, Bae HC (2009) Preparation of fermented milk added with powder of Opuntia ficus-indica var. Saboten and it's sensory characteristics. J East Asian Soc Dietary Life 19: 967-974

Lee SW (1988) The historical review of traditional Korean fermented foods. Kor J Dietary Culture 3: 331-339

Lee WJ, Lucey JA (2010) Formation and physical properties of yogurt. Asian-Aust Anim Sci 23: 1127-1136

Lee YJ, Kim SI, Han YS (2008) Antioxidant activity and quality characteristics of yogurt added yuza (Citrus junos Sieb ex Tanaka) extract. Korean J Food Nutr 21: 135-142

Liu X, Xiao G, Chen W, Xu Y, Wu J (2004) Quantification and Purification of mulberry anthocyanins with Macroporous Resins. J Biomed Biotechnol 5: $326-331$

Molin G (2001) Probiotics in foods not containing milk or milk constituents, with special reference to Lactobacillus plantarum 299v. Am J Clin Nutri 73: $380-385$

Nho HJ, Jang SY, Park JJ, Yun HS, Park SM (2013) Browning prevention of black carrot extract and the quality characteristics of jelly supplemented with black carrot extract. J Kor Soc Food Culture 28: 293-302

Park KY (1997) Carcinogenic stability, anti-mutagenic and anti-cancer function of traditional Korean fermented foods (Doenjang, Kimchi). Kor Soc Food Sci Technol 30: 89-102

Patras A, Brunton NP, O'Donnell C, Tiwari BK (2010) Effect of thermal processing on anthocyanin stability in foods; mechanisms and kinetics of degradation. Trends Food Sci Technol 21: 3-11

Sawatari Y, Sugiyama H, Suzuki Y, Hanaoka A, Saito K, Yamauchi H, Yokota A (2005) Development of fermented instant Chinese noodle using Lactobacillus plantarum. Food Microbiol 22: 539-546

Seppo L, Jauhiainen T, Poussa T, Korpela R (2003) A fermented milk high in bio-active peptides has a blood pressure-lowering effect in hypertensive subjects. Am J Clin Nutr 77: 326-330

Shin BK, Kang SA, Han JI, Park SM (2015) Quality and sensory characteristics of fermented milk adding black carrot extracts fermented with Aspergillus oryzae. J Korean Soc Food Culture 30: 370-376

Shin HS, Kim SM, Choi NK, Yang KH Kang MS (2009) The effect of fermented milk on viable cell count and biofilm formation of Streptococcus mutans. J Korean Acad Pediatr Dent 36: 358-366

Shin SM, Song KY, Seo KH, Yoon YC (2012) A study on the quality of soymilk-derived yogurt during storage. Kor J Dairy Sci Technol 30: 8392

Shin YS, Lee KS, Lee JS, Lee CH (1995) Preparation of yogurt added with aloe vera and its quality characteristics. J Korean Soc Food Nutr 24: 254-260

Suh HJ, Kim YS, Kim JM, Lee H (2006) Effect of mulberry extract on the growth of yogurt starter cultures. Korean J Food Sci Ani Resour 26: 144-147

Sung JM, Choi HY (2014) Effect of mulberry powder on antioxidant activities and quality characteristics of yogurt. J Korean Soc Food Sci Nutr 43: 690-697

Velioglu YS, Mazza G, Cao L, Oomah BD (1998) Antioxidant activity and total phenolics in selected fruits, vegetables, and grain products. J Agric Food Chem 46: 4113-4117

Yang JW, Jung SK, Song KM, Kim YH, Lee NH, Hong SP, Lee KH, Kim YE (2016) Quality characteristics of Sikhye added with mulberry (Morus alba L.) Fruit concentrate. J East Asian Soc Dietary Life 26: 44-54

Yeo JH, Lee KG, Kweon HY, Han SM, Park KH, Kim SS, Shin BS (2006) Application for dietary resources by silk protein. Korean J Seric Sci 48 : 6-10

Yim SH, Park JH, Nam SH, Song JH, Cho YS, Lee HC (2012) Properies characterization of tea functional component $G A B A$-containing fermeted milks. Kor Tea Soc 18: 56-68

Yuan Z, Xiaohong K, Yiqi H, Hui Y, Meilan W, Youhua, L, Guanghui X (2014) Effects of silkworm on lipid metabolism and serum adipose cytokine levels in rats with type 2 diabetes mellitus. Chinese Remedy Clinics 4: 003 